\title{
Human Rights Education in India: Perspectives and Practices
}

\author{
KM Ashifa ${ }^{1}$ \\ ${ }^{1}$ Asst.Professor in Social Work, School of Health Science, Istanbul Gelisim University, Istanbul -Turkey.
}

\begin{abstract}
Human rights education is highly relevant to promote protective mechanism against discrimination and equity among the people. It is a mechanism by which people learn about their rights and the rights of others in participative and immersive learning. "Human rights education in India became more relevant because the public received attention from nongovernmental organisations, the media and litigators of public concern to increasingly violated human rights, cases of custodian abuse, mass detentions without trial, bonded and child labour and environmental harm and the like"(Ashifa,2020). The work of the "National Commission for Human Rights (NHRC)" became more influential and led to this new ethos. The present investigation tried to identify the human rights education initiative by various governmental and nongovernmental organizations in India.
\end{abstract}

Keywords

Human Rights Learning and Practice; Education, Sustainability, development.

\section{Introduction}

Human rights education is "highly relevant to promote protective mechanism against discrimination and equity among the people. It is a mechanism in which people learn about their rights and the rights of others through participatory and immersive learning"(Abdi, A. A., \& Schultz, L.,2008). Human rights education seeks to improve perceptions and behaviors, develop new skills while encouraging collaborations, and to have an awareness of problems, enable people to express their rights and convey this information to others (Council of Europe, 2017). In a country like India, human rights education is more important to create a harmony and peaceful co-existence of cultures.

The present paper mainly deals with the initiatives of "National Human Rights Commission", "University Grants Commission" and initiatives of various NonGovernmental organization in promoting human rights education in India.

The promotion and protection of human rights and basic freedoms are global challenges which cannot be met without a major recognition and understanding of human rights issues. Global peace can be reached by recognizing the ideals of human rights and by imbibing them (Jayakumar, 2007). Participation of citizens needed to settle disputes over human rights. "Humanrights education is designed to provide skills and knowledge that enable them to change their lives with human rights principles and values" (Dias, 2005). For this reason, interactive, learner-centred methods are widely promoted to impart human rights education. It is an education about human rights for human rights.It is an activity to "foster and promote human rights culture and is a deliberate, participatory practice aimed at empowering individuals, with internationally recognized humanrights principles. As a medium to long-term process, human rights education seeks to inculcate critical thinking and integrate the cognitive, affective and attitudinal dimensions" (Amnesty International, 2007). Its goal is "to build a culture of respect for and action in the defence and promotion of human rights for all" (United Nations Children's Fund, 2007). An institutional framework of human rights education in India is given in figure 1 .

\section{Review of Literature}

Human rights education must be introduced at all levels of education ( Dharmaraj, 2010). "Human rights education cannot be an intellectual exercise" (Nieuwenhuis, J. (2007).It serves as a liaison between classroom education and social developments. Human rights studies should be included in schools and colleges' curricula or curricula, making it an important part of the learning process. India recognized primary education as one of everybody's fundamental needs.The Constitution allows all children aged 6-14 to receive free education (Ashifa,2013). Kaur (2009) mentioned that "the promotion and protection of human rights in a plural society like India has its own context and specificity. The societal violation of human rights havenecessitated the introduction of human rights education at all level of school education and education of teachers. Appreciation of values of human rights should move beyond declarations and become a reality and way of life". Human rights awareness in India has crossed only the preliminary 
milestones towards the journey of achieving the objectives of human rights education. There are many more milestones to go by developing a holistic plan of actions with clean objective of human rights

Figure 1

Institutional Frame work of HRE in India

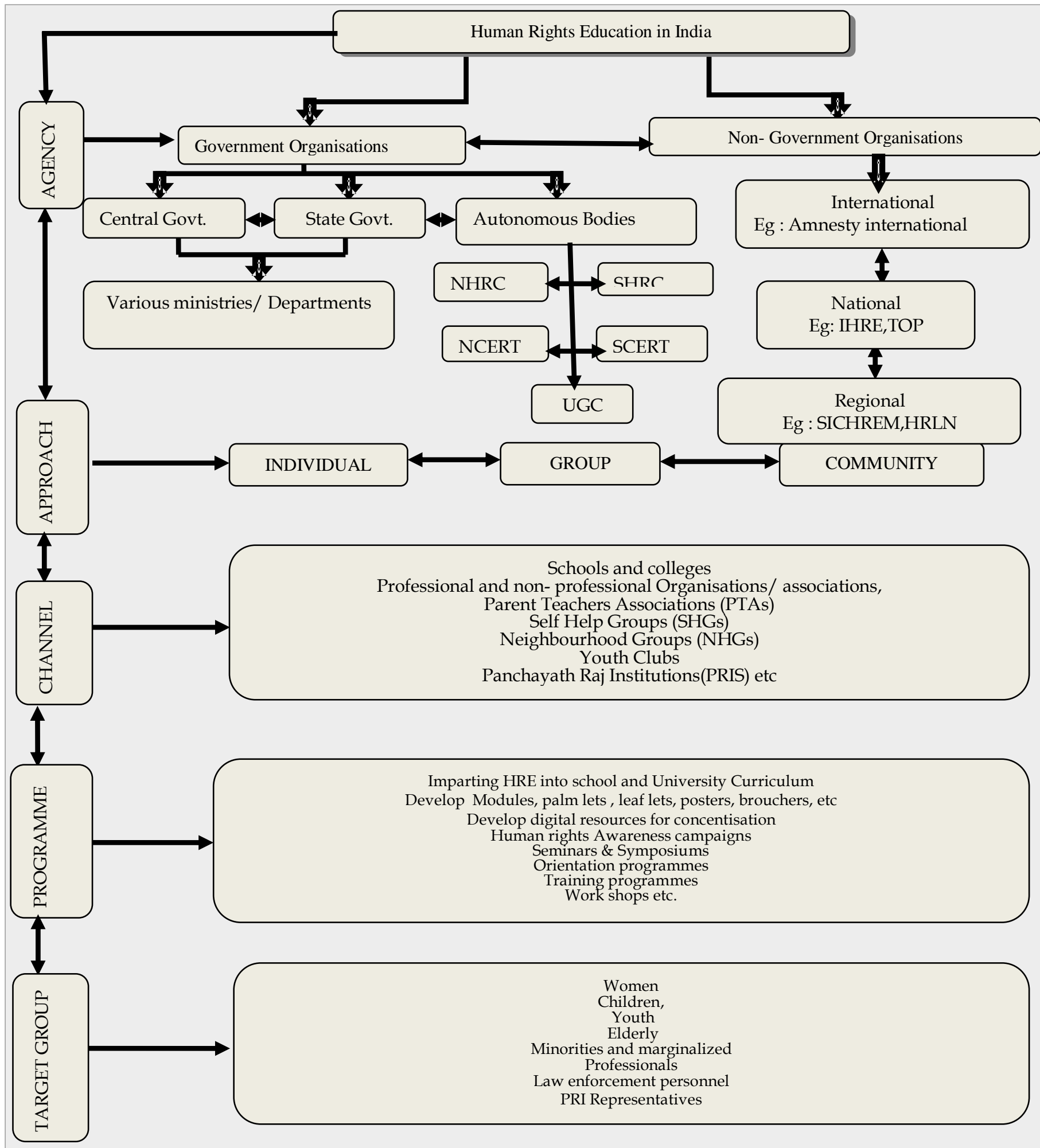

"It is essential to develop a counterpoint to the way in which social justice is used in progressive education by inviting students to examine critically the 
epistemological and axiological dimensions of social democracy so that they might begin to reclaim public life from its embeddedness in the corporate academiccomplex. It is precisely this challenge that has been taken up and exercised with much success by the authors of this important collection" (Cole,2006). "Human rights education is a concept that is subjected to an unexplored and unexplained conceptual eclecticism that hampers its pedagogical potentials as a counter measure to human rights violations and human suffering" (Keet,2006).

\section{Methods and Materials}

The present investigation tried to identify the human rights education initiative by various governmental and non-governmental organization in India. Document analysis were the major method used to get actual inference of human rights education programme in India. Researcher analysed various annual reports of National Human Rights Commission, Kerala human Rights Commission, National and state legal service authority, programme report of university grant commission and annual report of various NonGovernmental organization especially Jananeethi Thrissur Kerala.

\section{Result and Discussion}

Initiatives NHRC and State Legal Service authority on Human Rights Education:

The central as well as state governments of India perpetuate human rights education. "The National Human Rights Commission (NHRC) is an expression of India's concern for the protection and promotion of human rights ever since its inception in 1993"(NHRC, n.d). "NHRC has certain statutory obligations under Section 12 of the Human Rights Protection Act (1993), which could be better carried out in collaboration with universities. NHRC could entrust universities and teachers with investigation, collection of data, compilation of study reports, and visits on behalf of the commission. Areas and modalities of coordination between NHRC and the universities should be spelled out" (UNDP, 2010). "The Government of India had constituted a coordination committee under the Chairmanship of the Home Secretary, comprising secretaries of other ministries and concerned departments. The committee requested the NHRC to draw up a national plan of action for human rights education. Human rights education has been introduced for the forces, judicial officers and governmental officials. Through these commissions' efforts a significant national initiative has been institutionalized. Liaison and coordination are also envisaged among the commissions for women, religious minorities, linguistic minorities, scheduled castes, and scheduled tribes" (Singh, 2018).

A national network for "legal aid and assistance has been envisaged under the Act. The National Legal Services Authority (NALSA) is the apex body developing policies and principles for the provision of legal services under provisions of the Act and for the development of the most reliable and cost-effective legal systems" (NALSA, 2020). The State Legal Services Authority shall enforce the central authorities' policies and directions and provide citizens with legal services and conduct "Lok Adalats" in the State. "The State Legal Services Authority shall be headed by its Patron-in-Chief, the Chief Justice of the State High Court. A serving or retired High Court Judge shall be named Executive President of the Court. The District Legal Services Authority shall implement Legal Aid Programs and Systems in each district" (Ibid). The District Judge is its former Chief. The Taluk Legal Services Committees are also responsible for managing legal services programs in Taluk and organizing the "Lok Adalats". The "Taluk Legal Services Committee" is headed by a senior civil judge who is the former Chairman of the Committee. The agenda of the Legal Service Act was to include awareness of different areas of law and legal procedure. A number of awareness programs were organized by the Legal Service Authority, for undergraduate students at every college in Kerala; legal education for villagers, factory workers, tribal workers and other specialist groups; visits to Mental Health Centers and Psychiatric Hospitals, to provide legal assistance to mental health centres (Ibid).

\section{UGC on Human Rights Education:}

A committee was set up by the Indian University Grants Commission to discuss ways and means of supporting human rights education in India. The Committee recommended education on human rights at all stages. In 1997, the UGC formed a standing human rights education committee to start postgraduate and graduate courses in universities and colleges. As an autonomous academic discipline, several universities have adopted human rights. At university level, all disciplines should include human rights problems that are specifically linked to their disciplines. Training for human rights is also part of several university programs. It is interesting to note that today there are degrees, diploma, a postgraduate diploma and even a master's programme. The Human Rights Council of India has made it a compulsory subject for a degree in professional law. As a subject 
for the postgraduate law program, several universities offer human rights.

The UGC also encouraged university students to write books and monographs. We also funded conferences , workshops and symposiums on human rights issues. Human rights education has been introduced in the "National Curriculum System" (2005) by the "National Council on Education Study and Training" (NCERT). However, the NCERT performed its task by creating, from the International Charter, Pact and the Constitution of India, the sourcebook containing various aspects of human rights. According to the $\mathrm{NCF}$, in 2005, a culture of respect for human rights and peace should be given ample opportunity as it calls for respecting students ' personal experiences and for them to serve as a foundation for dialog and new learning. The "hallmarks of human rights education and peace education in India" have been the respect for human rights, justice , equality, collaboration, social responsibility, cultural diversity, a strong commitment to democracy and non-violent conflict resolution.

\section{Human Rights in Indian Universities and Colleges:}

Education is a effective tool to shape and alter people's attitudes. Unfortunately, only recently did the Indian education system start supporting human rights. The Indian Institute for Human Rights was founded as a component unit of the World Institution Building Program (WIBP), an international charity established by New Delhi in March 1990 with the goal of examining the urgent need for a national institution to be developed for studies, training, research, publishing, conference organization and consultancies at the national level. Indian Human Rights Institute had co-sponsorship at the bachelor, graduate and doctoral levels from approximately 37 central as well as state universities to initiate need-based programmes.

"The National Law School of India University in Bangalore" offers a full Human Rights course to the Bachelor of Laws. Human rights education in the departments of political science is only a small part of India's (fundamental rights) and International relations (United Nations) constitutional and political development course. "Human rights education is part of sociology, economics and modern Indian culture in some universities". No university offers a master's degree in human rights law exclusively. Human rights are taught in political science departments only in one or two classes. A number of prominent and accredited AICTE institutions offer PG human rights diploma courses through distance learning methods such as IGNOU, Kota Open University, Indian University
National Law School, and Woman's University, Mumbai.

NGO Initiative to Promote Human Rights Education:

The Non- governmental organizations are also involved in promoting human rights education at the national and international levels. The "Amnesty International, Red Cross Society, Institute of Human Rights Education (IHRE), South India Cell for Human Rights Education and Monitoring (SICHREM) and Human Rights Law Network (HRLN)" are grossly involved at imparting human rights education. UNESCO has a separate wing for human rights and provides study grants for undertaking projects on human rights. UNESCO's World programme for human rights education made specific efforts in widening knowledge on human rights in Asiatic region especially in India. The collaboration of both governmental and non-governmental organizations made significant contributions with focus on rights based approach. Their approach for human rights education is mostly community centred involving groups of children, youth, minorities marginalized women and even elderly in India. "The National Service Scheme (NSS), National Cadet Corps (NCC), Youth Clubs, Self-help groups, Neighbour-Hood groups (NHG)" and professional organisations were also associated in human rights campaigns. There were even protests and agitations against human rights violations. The advocacy efforts can empower the people on human rights restoration and protection for sustainable development.

In the state of Kerala there is a number of nongovernmental organizations working in the field of human rights. Under the section 12(i) of the Act, it is compulsorily required that the commission encourage the effort of NGO and institutions working in the field of human rights with the view to spread human rights literacy amongst various sections of the people and also to promote awareness for protection of human rights. KSHRC has given recognition to NGOs and permits them to conduct campaigns and there by encourages their work. At the beginning there were eleven NGO's registered under the commission. But the commission cancelled that recognition due to the ideological conflict among the organizations. The voluntary organizations have great role in spreading human rights awareness and propagation of human rights education. They published documents for educating masses in the matter of human rights, women rights and child rights. People's council for action, TOP (Torture prevention center) People's watch Kerala, South Indian cell for Human rights education and monitoring (SICHREM), CHRO 
(Confederation of Human Rights Organization), Amnesty international - Kerala chapter, Jana NeethiThrissur, were major human rights organizations in Kerala. They did an enthusiastic effort for spreading human rights awareness to the various sections of the society by means of organizing campaigns, workshops and seminars.

\section{Conclusion}

Human rights education can usually be referred to as an endeavor to foster and foster the culture of human rights. Human rights education is a deliberate, participatory activity that encourages awareness, skills and behaviors that are in line with globally accepted standards of human rights, empowering individuals , groups and communities. Human rights education is aimed at encouraging critical thought and incorporating human rights cognitive, affective, and attitude aspects. Its aim is to create a culture of harmony in a knowledge-based society for peaceful coexistence and sustainable development.

\section{Reference}

[1] Abdi, A. A., \& Schultz, L. (2008). Educating for Human Rights Global Citizenship. New York: State University of New York.

[2] Alston, P (2000).Human rights and Public Goods - Education as a Fundamental Right in India, Working paper 06. New York: Centre for Human rights and Global Justice.

[3] Amnesty International. (2007). Promoting Human Rights Education and Capacity Building. Retrieved from www.amnestymena.org: http://www.amnestymena.org/en/WhoWeAre/H umanRights Education.aspx?media=print

[4] Ashifa .KM (2020). Human rights Awareness and Advocacy role of Youth : An Empirical Analysis, Rupkatha Journal on Interdisciplinary Studies in Humanities, 12 (1).

[5] Ashifa K.M.(2019). Human Rights Awareness among Engineering Graduation Students. Journal of Advanced Research in Dynamical and Control Systems, 11 (special issue 12), 596598.

[6] Ashifa KM (2020). Human Rights Education Programme in Kerala: An Appraisal with Journal of Critical Reviews, 7(8).

[7] Ashifa,K.M.(2013). Advocacy Effort on Human Rights Education in Kerala: An Appraisal. Germany: Lambert.

[8] Bajwa, G. (1995). Human Rights in India Implementation and Violations. New Delhi:Anmol.
[9] Cole, M. (2006). Eudacation, Equality and Human Rights. New York: Routledge.

[10] Council of Europe. (2017). Introducing Human Rights Education. Retrieved from www.cor.int https://www.coe.int/en/web/compass/introducin g-human-rights-education

[11] Dharmaraj, N. (2010). Human Rights Violation among Women and Dalits and its economic Impact with Special refrence to Thriunelveli District. PhD thesis.

[12] Dias, C. J. (2005). Demiocracy and Human Rights : The Challenge of Ethnicity and Inclusive Demcracy. Jounral of the Indian Law Institute, 47(1).

[13] Flowers, N. (2000). The Human Rights Education Handbook: Effective Practices for Learning, Action, and Change. Minneapolis: University of Minnesota.

[14] Jayakumar, S. (2007). Human Rights Education - Role of Teachers. Western Regional Seminar. Khar: H.J. College of Education.

[15] Kaur, N. (2009). An Evaluative Study of Human Rights Education in the Curriculum of School Education in Punjab. Unpublished Ph.D Thesis, Guru Nanak Dev University, Amrtisar.

[16] Keet, A. (2006). Human Rights Education or Human Rights in Education : A Concelptual Analysis. Unpublished Ph.D Thesis, University of Pretoria, South Africa

[17] Kumar, S. (1995). Human Rights Movement in India- Role and intervention of NHRC. Human Rights Education in India, New Delhi: ISI.

[18] NALSA. (2020). National Legal Service Authority. Retrieved from www.nalsa.gov.in : https://nalsa.gov.in/about-us

[19] NHRC. (n.d). Protection of Human Rights . Retrieved from www.nhrc.in: https://nhrc.nic.in/sites/default/files/Unit_2.pdf

[20] Nieuwenhuis, J. (2007). Growing human rights and values in education. New York: Van Schaik.

[21] Singh, D. (1999). Human Rihgts and Judiciary in India: Contemporary Interface. Amritsar Law Journal, 9-10.

[22] Singh, L. (2018). The National Initiative on Human Rights Education in Schools and the Role of National Human Rights Commission. Human Rights Education in Asian Schools Volume I, https://www.hurights.or.jp/archives/human_rights_e ducation_in_asian_schools/section2/1998/03/thenational-initiative-on-human-rights-education-inschools-and-the-role-of-national-human-rightsc.html. 
[23]UNDP. (2010). UNDP-OHCHR Toolkit for collaboration with National Human Rights Institutions. New York: United Nations Human Rights .

[24] United Nations Children's Fund. (2007). A Human rights-based approach to Education for All: a framework for the realization of children's right to education and rights within education. New York: UNICEF 